\title{
Renewable organic waste as substrate conditioning for the production of Euterpe
}

\section{oleracea seedlings}

\author{
Resíduos orgânicos renováveis como condicionantes de substrato para produção de mudas de
}

Euterpe oleracea

Residuos orgánicos renovables como condiciones de sustrato para la producción de plántulas de

\section{Euterpe oleracea}

Received: 12/04/2021 | Reviewed: 12/09/2021 | Accept: 12/13/2021| Published: 12/21/2021

Amanda da Silva Reis
ORCID: https://orcid.org/0000-0001-8577-669X
Universidade Federal do Tocantins, Brasil
E-mail: areis176@gmail.com
Nayara Martins Alencar
ORCID: https://orcid.org/0000-0003-4981-5836
Universidade Federal do Tocantins, Brasil
E-mail: nayara_m1 @ hotmail.com
João Batista Fernandes da Cruz
ORCID: https://orcid.org/0000-0002-8207-6302
Universidade Federal do Tocantins, Brasil
E-mail: joaobatistapeixe10@ gmail.com
Maria Luara Aragão Silva
ORCID: https://orcid.org/0000-0003-2711-5783
Universidade Estadual do Maranhão, Brasil
E-mail: marialuaraaragao@gmail.com
Flavia Barreira Gonçalves
ORCID: https://orcid.org/0000-0001-8624-8637
Universidade Federal do Tocantins, Brasil
E-mail: flaviabarreira@ hotmail.com
Olavo da Costa Leite
ORCID: https://orcid.org/0000-0002-8959-0064
Universidade Federal do Tocantins, Brasil
E-mail: olavol @ hotmail.com
Antônio Clementino dos Santos
ORCID: https://orcid.org/0000-0001-7943-7923
Universidade Federal do Tocantins, Brasil
E-mail: clementino@ mail.uft.edu.br

\begin{abstract}
Forest restoration has the premise of restoring degraded native vegetation to conditions prior to degradation. The objective of this work was to evaluate the production of seedlings of a native species from the Amazon biome (Euterpe oleracea) under different substrates. The experiment was carried out at the Federal University of Tocantins, using a completely randomized design, and a 5x 4 factorial scheme, with five substrates (babassu stem + soil, babassu stem + rice husk + soil, coconut fiber + soil, babassu stem + fiber coconut + rice husk + soil, commercial substrate + soil - control), four trial periods (50, 100, 150 and 200 days). The evaluated variables: plant height, stem diameter, shoot dry matter, root dry matter, total dry matter, seedling quality index, leaf area and absolute growth rate. The growth of assai seedlings was influenced by the different substrates, until the 150 days after transplanting the quality and development of the seedlings were the same, both for the treatments that used commercial substrate and for the treatments that used renewable materials in their composition. The treatment using babassu stem (T1) obtained better shoot dry matter, total dry matter and seedling quality index values, in addition to being a material found in abundance in the regions, making this treatment the most viable and recommended for the production of assai seedlings.
\end{abstract}

Keywords: Amazon biome; Babassu stem; Rice husk; Coconut fiber; Alternative agriculture; Crop residues; Silviculture.

\section{Resumo}

A recomposição florestal tem premissa de restituir a vegetação nativa degradada às condições prévias a degradação. Objetivou-se nesse trabalho, avaliar a produção de mudas de uma espécie nativa do bioma Amazônia (Euterpe oleracea) sob diferentes substratos. O experimento foi realizado na Universidade Federal do Tocantins, utilizando 
delineamento inteiramente casualizado, e arranjo fatorial 5x 4, com cinco substratos (caule de babaçu + solo, caule de babaçu + casca de arroz + solo, fibra de coco + solo, caule de babaçu+ fibra de coco+ casca de arroz+ solo, substrato comercial+ solo- testemunha), quatro períodos de avaliações (50,100, 150 e 200 dias). As variáveis avaliadas: altura da planta, diâmetro do caule, massa seca da parte aérea, massa seca da raiz, massa seca total, índice de qualidade das mudas, área foliar e taxa de crescimento absoluto. O crescimento das mudas de açaí foi influenciado pelos diferentes substratos, até os 150 dias após transplantio a qualidade e desenvolvimento das mudas, foram iguais, tanto para os tratamentos que utilizaram substrato comercial, como para os tratamentos que utilizaram os materiais renováveis em sua composição. O tratamento que utiliza o caule de babaçu (T1) obteve melhores valores de massa seca da parte aérea, massa seca total e índice de qualidade das mudas, além de ser um material encontrado em abundância nas regiões, fazendo desse tratamento, o mais viável e recomendado para produção de mudas de açaí.

Palavras-chave: Bioma Amazônico; Caule de babaçu; Casca de arroz; Fibra de côco; Agricultura alternativa; Resíduos de colheitas; Silvicultura.

\section{Resumen}

La restauración forestal tiene como premisa restaurar la vegetación nativa degradada a las condiciones previas a la degradación. El objetivo de este trabajo fue evaluar la producción de plántulas de una especie nativa del bioma amazónico (Euterpe oleracea) bajo diferentes sustratos. El experimento se llevó a cabo en la Universidad Federal de Tocantins, utilizando un diseño completamente aleatorizado, y un arreglo factorial $5 \times 4$, con cinco sustratos (tallo de babasú + suelo, tallo de babasú + cáscara de arroz + suelo, fibra de coco + suelo, tallo de babasú + fibra de coco + cáscara de arroz + suelo, sustrato comercial + suelo control), cuatro periodos de prueba (50, 100, 150 y 200 días). Las variables evaluadas: altura de planta, diámetro de tallo, masa seca de brotes, masa seca de raíz, masa seca total, índice de calidad de plántula, área foliar y tasa absoluta de crecimiento. El crecimiento de las plántulas de açaí estuvo influenciado por diferentes sustratos, hasta que 150 días después del trasplante, la calidad y desarrollo de las plántulas fueron iguales, tanto para tratamientos que usaron sustrato comercial como para tratamientos que usaron materiales renovables en su composición. El tratamiento con tallo de babasú (T1) obtuvo mejor masa seca de brote, masa seca total e índice de calidad de plántula, además de ser un material que se encuentra en abundancia en las regiones, haciendo de este tratamiento el más viable y recomendado para la producción de plántulas de açaí.

Palabras clave: Bioma amazónico; Tallo de babasú; Cáscara de arroz; Fibra de coco; Agricultura alternativa; Residuos de cultivo; Silvicultura.

\section{Introduction}

Global agricultural production has increased significantly in recent years and the anthropogenic conversion of natural environments for human use, which modify and transform a large proportion of the planet's land surface (Foley et al., 2011), bringing short- and long-term environmental implications (Lambin \& Meyfroidt, 2011), is inherent to this.

In Brazil, it is essential to consider the implications arising from this conversion in the Cerrado biome, which covers about 204 million hectares (approximately 24\% of the Brazilian territory) and is home to 12,070 species of important land plants, in addition to containing the springs of the three largest river basins in South America in its territorial space, which contribute considerably to the water resources of the country's river basins (Forzza et al., 2015).

The Cerrado has undergone large-scale changes in recent decades, mainly in relation to the ecosystem function and use; however, the severity and consequences of these changes are less prominent on the national scene than those that occurred in the Amazon (Sawyer, 2008; Janssen, Rutz, 2011; Hunke et al., 2014). The expansion of the Brazilian agricultural frontier is one of the main causes of degradation in the Cerrado biome, however, it still suffers from the extremely predatory exploitation of its woody material for charcoal production (Mma, 2020)

Today, Law No. 12,651, of May 25, 2012, which mentions the new Brazilian forest code, is the main regulation aimed at protecting the natural vegetation on rural properties in the country (Sparovek et al., 2010), representing 329 million hectares distributed throughout the country's rural territory (Ibge, 2016).

The rural producer has several alternatives to adapt to the law regarding environmental liabilities. In areas deforested until July 2008, regularization can be done through recovery (either directed or natural, that is, natural recomposition or regeneration) or compensation (Azevedo, Stabile, Reis, 2015; Brasil, 2012a).

The National Policy for the Recovery of Native Vegetation (PLANAVEG), which is one of the ways the government can overcome the challenge of implementing Law No. 12,651, of May 25, 2012 (Pacheco et al., 2017), is aimed at expanding 
and strengthening public policies, financial incentives, markets, among other measures necessary for the recovery of native vegetation of up to 12 million hectares by 2030, mainly in permanent preservation areas (PPA) and legal reserve (LR), but also in degraded areas with low productivity (MMA, 2018).

Through such projections, it is clear that the availability of seeds and native forest seedlings will be essential for the effective fulfillment of the legal requirements for regularization and for the international commitment assumed. (Daldegan \& Sambuichi, 2017).

In Brazil, assai is one of the non-wood forest products that has gained a prominent space in the national and international food markets. The production and export data of this fruit denote its great economic potential (Conab, 2017; Serra, 2020), a fact that is related to the commercialization of the fruit (fresh and pulp) and of the stem (palm heart) (Honório et al., 2017).

Studies that provide information about the compounds present in assai emphasize the presence of bioactive substances, especially those related to phenolic compounds and pigments, such as anthocyanins, flavonoids and carotenoids, which make assai an excellent source of bioactive and phenolic compounds (Peixoto et al., 2016; Carneiro et al., 2020).

Observing the volume of assai exported by Brazil in the last 5 years, it is possible to notice the evolution in the absolute indexes, despite the fluctuations over the period, and there is also an evolution in the percentage in relation to the total amount produced in the country. In the state of Tocantins, assai production was 3 tons in 2011 and 2012, and 1 ton in 2017 (Serra, 2020).

In the north of the Brazil the consumption and export of assai have driven family farming to grow the species, triggering a new format of family farming, more exploratory than sustainable, with a focus on Agroforestry systems as an alternative for the production of assai, having agroecology as a basic principle (Brito Almeida et al., 2021).

In the state of Tocantins, producers have been investing in the cultivation of assai in the state since 2016. The planting of species adapted to the state's climate - with seedlings produced in local nurseries - is under development, occupying an area of about 150 hectares, but with plans to expand the project to 250 hectares and later on to 400 hectares (Batista, 2021) so as to increase production.

For seedling production, organic residues are sources of nutrients frequently used in the composition of the substrate. They play a relevant role in improving physical attributes, in addition to stimulating microbial processes (Delarmina et al., 2015).

Caldeira et al. (2013) state that substrates formulated with organic waste (sewage sludge, coffee straw, and rice husk) provide greater growth of the seedlings of Chamaecrista desvauxii, as in their study, treatments with a greater increase in sewage sludge, in relation to the others (60:20:20), positively affect the growth and morphological characteristics of the seedlings (plant height, stem diameter, shoot dry matter, root dry matter, total dry matter, seedling quality index)

In this sense, the objective of this work was to evaluate the production of seedlings of the species Euterpe oleracea (assai from Pará) under different substrates, composed of renewable materials - coconut fiber, fresh rice husk, Babassu (decomposed stem) - found locally.

\section{Methodology}

The experiment was installed and conducted from June 2019 to January 2020, in a shade environment (shading of $50 \%$ ), at the School of Veterinary Medicine and Animal Science (EMVZ) of the Federal University of Tocantins, in the Araguaína campus, located in the north of the state of Tocantins under coordinates $7^{\circ} 06^{\prime} 16^{\prime \prime} \mathrm{S}$ and $48^{\circ} 12^{\prime} 04^{\prime \prime} \mathrm{W}$. The region has a climate classified (Köppen) as Aw (Tropical with dry winter), with an average annual precipitation of $1828 \mathrm{~mm}$ and an average temperature of $26^{\circ} \mathrm{C}$. 
Polyethylene packages with a volumetric capacity of $5 \mathrm{dm}^{3}$ were used, with dimensions of $30 \mathrm{x} 35 \mathrm{~cm}$. The soil used to prepare the substrates was classified according to Embrapa, as Red Yellow Ultisol and has the following chemical characteristics: $\mathrm{pH}=(\mathrm{Ca} \mathrm{Cl}) 5.4, \mathrm{Ca}=18.56 \mathrm{cmolc} / \mathrm{dm}^{-3}, \mathrm{Mg}=2.15 \mathrm{cmolc} / \mathrm{dm}^{-3}, \mathrm{~K}=0.04 \mathrm{cmolc}^{-} \mathrm{dm}^{-3}, \mathrm{H}+\mathrm{Al}=3.20$ cmolc $/ \mathrm{dm}^{-3}, \mathrm{P}=1.35 \mathrm{mg} / \mathrm{dm}^{-3}, \mathrm{CTC}($ at $\mathrm{pH} 7)=23.95 \mathrm{cmolc} / \mathrm{dm}-3$, base saturation $=86.63 \%$, aluminum saturation $=0.48 \%$, organic matter $=7.26 \mathrm{~g} / \mathrm{kg}^{-1}$.

The materials used in the composition of the substrates are considered by-products, and are destined for burning, or for inappropriate disposal by the local population, namely fresh rice husks, coconut fiber and decomposed babassu stem (Attalea speciosa). All materials were air-dried, and the coconut fiber and babassu stem passed through a $10 \mathrm{~mm}$ crusher, for better homogenization of the substrate.

The pre-germinated assai seeds (Euterpe oleracea) used in the experiment were purchased from the local market, as well as the commercial substrate Topstrat- Vida verde, used in the control substrate, with the following composition described on the packaging: pine bark, coconut fiber, vermiculite, carbonized rice husk, simple superphosphate, limestone, PG Mix 4.16.18 and potassium nitrate.

Table 1 shows the values of macronutrients and $\mathrm{pH}$ found in the by-products used in the composition of the substrates.

Table 1- Values of $\mathrm{pH}$, nitrogen $(\mathrm{N})$, phosphorus $(\mathrm{P})$, potassium $(\mathrm{K})$, calcium $(\mathrm{Ca})$, magnesium $(\mathrm{Mg})$ in percentage, of the materials used in the composition of the substrate.

\begin{tabular}{c|ccccc|c}
\hline \multirow{2}{*}{ Material } & $\mathbf{K}$ & $\mathbf{P} \%$ & $\mathbf{C a}$ & $\mathbf{M g}$ & $\mathbf{N} \%$ & \multirow{2}{*}{$\mathbf{p H}$} \\
\cline { 2 - 5 } & \multicolumn{7}{|c}{$(\%)$} & 2.75 & 0.91 & 5.60 \\
FRH & 12.20 & 6.76 & 5.29 & 2.16 & 1.16 & 4.35 \\
CF & 7.76 & 6.17 & 2.19 & 11.94 & 2.08 & 5.80 \\
B & 17.11 & 7.08 & 21.31 & \\
\hline
\end{tabular}

FHR- Fresh rice husk, CF- Coconut fiber, B- Babassu. Source: Authors.

The experimental design was completely randomized (CRD), in a 5x4 factorial scheme, five substrates, four evaluation dates and 4 replications. The substrates used were: T1- Babassu stem + soil: BS (2:1), T2- Babassu stem + rice husk + soil: BSRH (1:1:1), T3- coconut fiber + soil: SCF (2:1), T4 - Babassu stem + coconut fiber + rice husk + soil: SBRHCF (1:1:1:1), T5- Commercial substrate + soil: SCS- Control (1:2). The evaluation dates were at 50, 100, 150 and 200 days.

The variables analyzed were plant height $(\mathrm{cm})$, obtained with the aid of a measuring tape, at the level of the substrate to the apex of the aerial part, stem diameter $(\mathrm{mm})$, measured at the base of the stem with a caliper, number of leaves (open leaves), height diameter ratio - H/ D, root dry mass - RDM (g), shoot dry mass - SDM (g) and total dry mass - TDM (g) were obtained destructively, with the roots being separated from the shoot, washed in sieves and then packed in paper bags, for subsequent drying in an oven with forced air circulation at $55^{\circ} \mathrm{C}$ until constant weight was obtained.

The leaf area $\left(\mathrm{cm}^{2} /\right.$ plant) variable was obtained through the product of the length $(\mathrm{cm})$ and width of the leaflets $(\mathrm{cm})$, multiplied by a factor of 0.6854 (Nogueira \& Conceição, 2000). The absolute growth rate (g. plant ${ }^{-1}$ day $^{-1}$ ) is given by the equation $\mathrm{AGR}=(\mathrm{W}) /(\mathrm{t})$, where $\mathrm{W}$ is the total weight of the dry matter of the plant, $\mathrm{t}$ is the elapsed time (Benincasa, 1988). The Dickson quality index-DQI was determined as a function of total dry mass-TDM, plant height-H, stem diameter-D, shoot dry mass-SDM, and root dry mass-RDM, according to the following formula ${ }^{(1)}$, (Dickson et al., 1960): 
An analysis of variance (ANOVA) was performed on all variables mentioned above, and those that did not have significant interactions $(\mathrm{P}>0.05)$ were not discussed. Some plants showed an incidence of Anthracnose disease, which ended up causing injuries to or death of some repetitions. Therefore, the treatment means were compared using the LSMEANS/PDIFF procedure $(\mathrm{P}<0.05)$ in the Statistical Analysis Software program (SAS Institute Inc. 1996), in which treatments were considered different when $\mathrm{P} \leq 0.05$.

\section{Results and Discussion}

There was interaction $(\mathrm{P}<0.05)$ between treatments and days after transplanting (DAT) the seedlings, for all variables analyzed, except for the height/stem diameter variable, which was only influenced by the isolated effect of the days (Table 2).

Table 2. Mean values of the plant height (H), stem diameter (D), height and diameter ratio (H/D) variables of assai seedlings (Euterpe oleracea) evaluated at different times after transplanting and in response to different treatments. Araguaína, Tocantins, 2019.

\begin{tabular}{|c|c|c|c|c|c|c|c|c|}
\hline \multirow{3}{*}{ Days } & \multicolumn{5}{|c|}{ Substrates ${ }^{(1)}$} & \multirow{3}{*}{ Mean } & \multirow{3}{*}{$\mathrm{CV} \%$} & \multirow{3}{*}{ P-value } \\
\hline & \multicolumn{5}{|c|}{$\mathrm{H}(\mathrm{cm})$} & & & \\
\hline & 1 & 2 & 3 & 4 & 5 & & & \\
\hline 50 & $26.30 \mathrm{Ca}$ & $22.45 \mathrm{Ba}$ & $23.15 \mathrm{Ca}$ & $22.62 \mathrm{Ca}$ & $26.32 \mathrm{Da}$ & 24.17 & \multirow{5}{*}{11.21} & \multirow{5}{*}{0.001} \\
\hline 100 & $27.17 \mathrm{Cb}$ & $27.87 \mathrm{Bb}$ & $26.60 \mathrm{Cb}$ & $32.77 \mathrm{Ba}$ & $36.35 \mathrm{Ca}$ & 30.35 & & \\
\hline 150 & $36.36 \mathrm{Bb}$ & $34.25 \mathrm{ABb}$ & $42.00 \mathrm{Bb}$ & $38.30 \mathrm{Bb}$ & $53.92 \mathrm{Ba}$ & 40.97 & & \\
\hline 200 & $53.27 \mathrm{Ab}$ & $36.06 \mathrm{Ad}$ & $50.25 \mathrm{Ac}$ & $56.70 \mathrm{Ab}$ & $67.60 \mathrm{Aa}$ & 52.77 & & \\
\hline \multirow[t]{2}{*}{ Mean } & 36.02 & 30.16 & 35.5 & 37.6 & 46.05 & & & \\
\hline & & & $\mathrm{D}(\mathrm{mm})$ & & & & & \\
\hline 50 & $3.57 \mathrm{Ca}$ & $2.52 \mathrm{Ca}$ & $3.125 \mathrm{Ca}$ & $3.22 \mathrm{Da}$ & $3.42 \mathrm{Da}$ & 3.17 & \multirow{5}{*}{19.26} & \multirow{5}{*}{0.0174} \\
\hline 100 & $5.62 \mathrm{Cab}$ & $4.43 \mathrm{BC} \mathrm{b}$ & $4.60 \mathrm{Cb}$ & $6.20 \mathrm{Cab}$ & $7.06 \mathrm{Ca}$ & 5.58 & & \\
\hline 150 & $9.01 \mathrm{Bab}$ & $6.42 \mathrm{BC}$ & $8.48 \mathrm{BBC}$ & $9.73 \mathrm{Bab}$ & $11.10 \mathrm{Ba}$ & 8.95 & & \\
\hline 200 & 14.2 Ac & 9.70 Ad & $10.95 \mathrm{Ad}$ & $14.57 \mathrm{Ab}$ & 17.20 Aa & 13.32 & & \\
\hline \multirow[t]{2}{*}{ Mean } & 8.1 & 5.77 & 6.78 & 8.43 & 9.69 & & & \\
\hline & & & H/D & & & & & \\
\hline 50 & 7.82 & 8.9 & 7.52 & 7.12 & 7.75 & 7.82 & \multirow{5}{*}{19.15} & \multirow{5}{*}{0.8849} \\
\hline 100 & 5.08 & 6.34 & 5.83 & 5.37 & 5.2 & 5.56 & & \\
\hline 150 & 4.04 & 5.36 & 5.47 & 3.95 & 4.85 & 4.73 & & \\
\hline 200 & 3.79 & 4.04 & 4.63 & 3.97 & 3.94 & 4.07 & & \\
\hline Mean & 5.18 & 6.16 & 5.86 & 5.1 & 5.43 & & & \\
\hline
\end{tabular}

Lowercase letters compare means for the substrate factor ${ }^{(1)}$, uppercase letters compare means for the day factor ${ }^{(2)}$. Means within the row followed by the different uppercase letters and within the column by the different lowercase letters are statistically different using the LSMEANS / PDIFF $(\mathrm{P} \leq 0.05)$ procedure (SAS Institute Inc., 1996). Substrates (1): 1- Babassu stem + soil, 2- Babassu stem + rice husk + soil, 3 - coconut fiber + soil, $4-$ Babassu stem + coconut fiber + rice husk + soil, 5 Commercial substrate + soil. Source: Authors.

For the plant height $(\mathrm{H})$ and diameter (D) variables, all treatments at 50 DAT were statistically equal. At 100 DAT, treatments 5 and 4 had the highest height $(36.35 \mathrm{~cm}$ and $32.77 \mathrm{~cm})$ and diameter $(7.06 \mathrm{~mm}$ and $6.20 \mathrm{~mm})$ means. 
For plant height (Table 2), treatment 5 had the highest averages at 150 and 200 DAT $(53.92 \mathrm{~cm}$ and $67.60 \mathrm{~cm}$, respectively), differing from the others $(\mathrm{P}<0.05)$. This may be related to the superior chemical composition of the commercial substrate used in the composition of this treatment.

It was verified in this study that the lowest averages of plant height and stem diameter were found in treatments 2 and 3, which in their composition have lower percentage of macronutrients: $\mathrm{P}, \mathrm{N}, \mathrm{K}$ and $\mathrm{Mg}$ (Table 1), which are limiting the growth of assai seedlings (Viegas et al., 2004).

The absence of functionally acting nutrients such as potassium, which plays an important role in regulating the osmotic potential of plant cells, and activation of respiration and photosynthesis enzymes (Taiz et al., 2017), and has a direct influence on growth and development of the plants.

Treatments 4 and 1 (Table 2) obtained satisfactory mean height and diameter values at 200 DAT (Sousa et al., 2018). The values found for these treatments in the aforementioned variables may be related to the formulation of the substrate and the proportion of organic compounds: soil $(75: 25)$ that this treatment used. The addition of organic components in greater proportion has a positive effect on substrates for seedling production (Silva et al., 2015).

In their study, Sousa et al. (2018) obtained mean height and diameter similar at 90 days $(25.31 \mathrm{~cm}$ in height and 4.07 $\mathrm{mm}$ in diameter) as found in this experiment at 100 days, they concluded in their study that the substrate with organic compounds + sand, being the highest proportion for organic compost (75:25), provide higher mean height and diameter values in assai plants (Euterpe oleracea), and statistically equal to the commercial substrate used.

In the stem diameter variable, treatments 5, 4 and 1 at 150 DAT were statistically equal, and at 200 DAT, T5 had the highest significant mean value $(\mathrm{P}<0.05): 17.20 \mathrm{~mm}$.

Stem diameter is a variable that is a good indicator to assess the quality of seedlings. It is directly related to their survival and growth, after field plantation (Campos \& Uchida, 2002). Thus, one expects that plants produced with a smaller stem diameter will possibly have a lower survival rate at the time of transplantation in the definitive location (Correa et al., 2019).

In this study, from 100 DAT on, except for treatments 2 and 3, all treatments had mean values of stem diameter within the limit considered as ideal, with values ranging from $5.62 \mathrm{~mm}$ to $17.20 \mathrm{~mm}$. Gonçalves et al. (2000) report the values located between 5 and $10 \mathrm{~mm}$ in stem diameter, as suitable for seedlings of forest species, which can be considered as having a good standard of quality.

Treatment 2 was the one that obtained the lowest means of plant height and stem diameter throughout the evaluated days. Fresh coconut fiber and rice husk residues do not provide satisfactory growth of the morphological characteristics of seedlings (Delarmelina et al., 2014).

Caldeira et al. (2013), testing several components - coconut fiber, organic compound, fresh rice husk and fresh coffee straw - associated with sewage sludge, observed lower height growth in treatments using coconut fiber and fresh rice husk.

At 50 and 100 DAT, the shoot dry mass (SDM), root dry mass (RDM), and total dry mass (TDM) variables shown in Table 3 did not express statistical difference between treatments.

Treatment 5 had the highest means at 150 and 200 DAT in the SDM and TDM variables and differed statistically from the other treatments in both variables. This is possibly related to the composition of the commercial substrate, which has chemical fertilization, directly interfering with the increase and accumulation of the mass of leaves, stems and roots. Assai palm plants with nutritional deficits reduce dry mass by up to $70 \%$ when compared to fertilized plants (Viegas et al, 2008). 
Table 3. Analysis of variance for Shoot dry mass (SDM), Root dry mass (RDM), Total dry mass (TDM), Root/shoot ratio $(\mathrm{R} / \mathrm{S}$ ), and Dickson quality index (DQI) of seedlings of assai (Euterpe oleracea) evaluated at different times after transplantation and in response to different treatments. Araguaína, Tocantins, 2019.

\begin{tabular}{|c|c|c|c|c|c|c|c|c|}
\hline \multirow{3}{*}{ Days } & \multicolumn{5}{|c|}{ Substrates ${ }^{(1)}$} & \multirow{3}{*}{ Mean } & \multirow{3}{*}{$\mathrm{CV} \%$} & \multirow{3}{*}{ P-value } \\
\hline & \multicolumn{5}{|c|}{$\operatorname{SDMC}(\mathrm{g})$} & & & \\
\hline & 1 & 2 & 3 & 4 & 5 & & & \\
\hline 50 & $0.19 \mathrm{Ca}$ & $0.10 \mathrm{Ba}$ & $0.10 \mathrm{Ca}$ & $0.075 \mathrm{Ca}$ & $0.14 \mathrm{Ca}$ & 0.125 & \multirow{4}{*}{34.25} & \multirow{4}{*}{$<0001$} \\
\hline 100 & $0.65 \mathrm{Ca}$ & $0.64 \mathrm{Aba}$ & $0.69 \mathrm{Ca}$ & $1.07 \mathrm{Ba}$ & $1.04 \mathrm{Ca}$ & 0.82 & & \\
\hline 150 & $2.29 \mathrm{Bb}$ & $0.89 \mathrm{Ac}$ & $2.07 \mathrm{Bbc}$ & $3.05 \mathrm{Ab}$ & $4.67 \mathrm{Ba}$ & 2.59 & & \\
\hline 200 & $4.67 \mathrm{Ab}$ & $1.62 \mathrm{Ad}$ & $3.55 \mathrm{Ac}$ & $3.76 \mathrm{Abc}$ & $6.88 \mathrm{Aa}$ & 4.09 & & \\
\hline \multirow[t]{2}{*}{ Mean } & 1.95 & 0.81 & 1.6 & 1.99 & 3.18 & & & \\
\hline & & & $\operatorname{RDM}(\mathrm{g})$ & & & & \multirow{6}{*}{38.53} & \multirow{6}{*}{$<0001$} \\
\hline 50 & $0.40 \mathrm{Ca}$ & $0.32 \mathrm{Ba}$ & $0.23 \mathrm{Ca}$ & $0.34 \mathrm{Ba}$ & $0.33 \mathrm{Ca}$ & 0.32 & & \\
\hline 100 & $0.46 \mathrm{CA}$ & $0.58 \mathrm{Ba}$ & $0.53 \mathrm{Ca}$ & $0.58 \mathrm{Ba}$ & $0.65 \mathrm{Ca}$ & 0.56 & & \\
\hline 150 & $1.60 \mathrm{Ba}$ & $2.58 \mathrm{Aa}$ & $1.55 \mathrm{Ba}$ & $1.23 \mathrm{Bb}$ & $2.11 \mathrm{Ba}$ & 1.81 & & \\
\hline 200 & $4.87 \mathrm{Ab}$ & $2.82 \mathrm{Ac}$ & $3.37 \mathrm{Ac}$ & $3.45 \mathrm{Ac}$ & $6.14 \mathrm{Aa}$ & 4.13 & & \\
\hline \multirow[t]{2}{*}{ Mean } & 1.83 & 1.87 & 1.42 & 1.4 & 2.31 & & & \\
\hline & & & $\mathrm{TDM}(\mathrm{g})$ & & & & \multirow{6}{*}{32.86} & \multirow{6}{*}{$<0001$} \\
\hline 50 & $0.60 \mathrm{Ca}$ & $0.42 \mathrm{Ba}$ & $0.33 \mathrm{Ca}$ & $0.42 \mathrm{Ca}$ & $0.47 \mathrm{Da}$ & 0.45 & & \\
\hline 100 & $1.11 \mathrm{Ca}$ & $1.22 \mathrm{Ba}$ & $1.22 \mathrm{Ca}$ & $1.65 \mathrm{Ca}$ & $1.70 \mathrm{Ca}$ & 1.38 & & \\
\hline 150 & $3.89 \mathrm{Bb}$ & $3.47 \mathrm{Ab}$ & $3.63 \mathrm{Bb}$ & $4.28 \mathrm{Bb}$ & $6.78 \mathrm{Ba}$ & 4.41 & & \\
\hline 200 & $9.55 \mathrm{Ab}$ & $4.44 \mathrm{Ad}$ & $6.92 \mathrm{Ac}$ & $7.21 \mathrm{Ac}$ & $13.03 \mathrm{Aa}$ & 8.23 & & \\
\hline Mean & 3.79 & 2.39 & 3.02 & 3.39 & 5.49 & & & \\
\hline
\end{tabular}

Lowercase letters compare means for the substrate factor (1), uppercase letters compare means for the day factor (2). Means within the row followed by the different uppercase letters and within the column by the different lowercase letters are statistically different using the LSMEANS / PDIFF (P $\leq$ 0.05) procedure (SAS Institute Inc., 1996). Substrates (1): 1- Babassu stem + soil, 2- Babassu stem + rice husk + soil, 3- coconut fiber + soil, 4 - Babassu stem + coconut fiber + rice husk + soil, 5 - Commercial substrate + soil. Source: Authors.

The SDM value found at 150 DAT for Treatment 5, 4.57 is close to the value found by Sousa et al. (2018) (4.77 g), who used commercial substrate $(100 \%)$ with composition similar to that used in this study.

Despite not having any type of chemical fertilizer added to its composition, Treatment 1 had the second highest average of SDM, RDM and TDM at the end of the experiment, and this may be a consequence of the nutrient content (Table 1) of the material used in the formulation of this treatment. According to Oliveira et al. (2002), macronutrients directly interfere in the production of total dry mass in young plants in the following order: $\mathrm{K}>\mathrm{Mg}>\mathrm{P}>\mathrm{N}>\mathrm{Ca}>\mathrm{S}$, while, according to Ribeiro Araújo et al. (2016), the assai palm has leaf dry mass production affected by the omission of $\mathrm{P}>\mathrm{Cu}>\mathrm{N}>\mathrm{K}>\mathrm{Mg}$ at an average of $31.9 \%$.

The absence of fertilization and liming in the treatments can reduce root dry mass gain by more than 50\% (Ribeiro Araújo et al., 2016), as occurred in treatments T2, T3 and T4.

This is because nutrients with a structural function in the plant such as nitrogen $(\mathrm{N})$ and phosphorus $(\mathrm{P})$ are required in greater quantity. $\mathrm{N}$ contributes to the increase of plant biomass and acts as a component of chlorophyll, participates in the photosynthesis process (Sousa \& Lobato, 2002) and P participates in compounds and vital reactions for plants (6P glucose, 6P fructose, membrane phospholipids, among others). Under favorable environmental conditions, these nutrients increase the efficiency of the use of solar radiation, which increases the accumulation of dry matter and plant production (Taiz et al., 2017). 
In their study with pupunha palm (from same family as the assai palm tree), Fernandes et al. (2013) found the decreasing order of macronutrient accumulation $\mathrm{N}>\mathrm{K}>\mathrm{Ca}>\mathrm{P}>\mathrm{Mg}>\mathrm{S}>\mathrm{Na}$, confirming that these nutrients are determinant in the development and increase of mass of the species.

Regarding the variable TDM (Table 3) among the treatments with renewable materials used in the composition of the substrate, treatment 1 presented a greater increase in total dry mass when compared to the others and was inferior only to treatment 5 a fact that can be explained by the higher $\mathrm{N}$ and $\mathrm{K}$ contents found in substrates with higher amounts of decomposed babassu stem (De Andrade et al, 2017).

The total dry mass variable allows for the analysis of plant growth, with the total amount of dry matter accumulated by the plant being a direct result of the net photosynthetic production, plus the amount of mineral nutrients absorbed (Dapont; Silva; Alves, 2016).

According to Smirdele et al. (2020) treatments with up to $25 \%$ of sand and $25 \%$ of burnt rice husk are indicated for the production of Euterpe oleracea Mart. seedlings, as they provide superior growth in plant height and stem diameter, in addition to improving the increase in total plant dry mass.

The Dickson Quality Index - DQI (Table 4) of the treatments did not differ from each other $(\mathrm{P}>0.05)$ at 50,100 , and 150 DAT, demonstrating that, up to 150 DAT, the seedlings within the treatments had the same development and quality index.

Table 4. Mean values of Dickson Quality Index (DQI), Leaf Area (LA), Absolute Growth Rate (AGR), of assai seedlings (Euterpe oleracea) evaluated at different times after transplantation and in response to different treatments. Araguaína, Tocantins, 2019.

\begin{tabular}{|c|c|c|c|c|c|c|c|c|}
\hline \multicolumn{9}{|c|}{ Substrates $^{(1)}$} \\
\hline Days & 1 & 2 & 3 & 4 & 5 & Mean & $\mathrm{CV} \%$ & P-value \\
\hline \multicolumn{9}{|c|}{ DQI } \\
\hline 50 & $0.079 \mathrm{Ca}$ & $0.047 \mathrm{Ca}$ & $0.043 \mathrm{Ca}$ & $0.057 \mathrm{Ca}$ & $0.059 \mathrm{Ca}$ & 0.057 & \multirow{5}{*}{44.32} & \multirow{5}{*}{0.0001} \\
\hline 100 & $0.171 \mathrm{Ca}$ & $0.16 \mathrm{Bca}$ & $0.173 \mathrm{Bca}$ & $0.23 \mathrm{Ca}$ & $0.24 \mathrm{Ca}$ & 0.197 & & \\
\hline 150 & $0.722 \mathrm{Ba}$ & $0.61 \mathrm{Aba}$ & $0.57 \mathrm{Ba}$ & $0.64 \mathrm{Ba}$ & $0.95 \mathrm{Ba}$ & 0.702 & & \\
\hline 200 & $2.06 \mathrm{Ab}$ & $0.98 \mathrm{Ad}$ & 1.22 Acd & $1.44 \mathrm{Ac}$ & $2.58 \mathrm{Aa}$ & 1.16 & & \\
\hline Mean & 0.758 & 0.453 & 0.504 & 0.594 & 0.962 & & & \\
\hline \multicolumn{9}{|c|}{ LA $\left(\mathrm{cm}^{2} /\right.$ plant $)$} \\
\hline 100 & $55.17 \mathrm{Ba}$ & $61.68 \mathrm{Ba}$ & $60.83 \mathrm{Ba}$ & $60.14 \mathrm{Ba}$ & $54.83 \mathrm{Ba}$ & 58.53 & \multirow{4}{*}{34.79} & \multirow{4}{*}{0.0197} \\
\hline 150 & $137.31 \mathrm{AB} b c$ & $71.62 \mathrm{Bc}$ & 117.43 ABbc & $175.12 \mathrm{Ab}$ & $262.596 \mathrm{Aa}$ & 152.81 & & \\
\hline 200 & 194.14 Ab & $193.96 \mathrm{Ab}$ & $154.21 \mathrm{Ab}$ & $229.49 \mathrm{Ab}$ & $331.04 \mathrm{Aa}$ & 220.57 & & \\
\hline Mean & 128.87 & 109.09 & 110.82 & 154.91 & 216.15 & & & \\
\hline \multicolumn{9}{|c|}{$\operatorname{AGR}\left(\mathrm{g}_{\text {plant }}{ }^{-1}\right.$ day $\left.^{-1}\right)$} \\
\hline 100 & $0.011 \mathrm{Ca}$ & $0.012 \mathrm{Aa}$ & $0.012 \mathrm{Ba}$ & $0.016 \mathrm{Ba}$ & $0.017 \mathrm{Ca}$ & 0.013 & \multirow{3}{*}{26.45} & \multirow{3}{*}{0.0015} \\
\hline 150 & $0.026 \mathrm{Bb}$ & $0.023 \mathrm{Ab}$ & $0.024 \mathrm{Ab}$ & $0.028 \mathrm{Ab}$ & $0.045 \mathrm{Ba}$ & 0.029 & & \\
\hline 200 & $0.047 \mathrm{Ab}$ & $0.022 \mathrm{Ab}$ & $0.034 \mathrm{Ac}$ & $0.036 \mathrm{Ac}$ & $0.065 \mathrm{Aa}$ & 0.041 & & \\
\hline Mean & 0.028 & 0.019 & 0.023 & 0.027 & 0.042 & & & \\
\hline
\end{tabular}

Lowercase letters compare means for the substrate factor ${ }^{(1)}$, uppercase letters compare means for the day factor (2). Means within the row followed by the different uppercase letters and within the column by the different lowercase letters are statistically different using the LSMEANS / PDIFF $(\mathrm{P} \leq$ 0.05) procedure (SAS Institute Inc., 1996). Substrates (1): 1- Babassu stem + soil, 2- Babassu stem + rice husk + 
soil, 3 - coconut fiber + soil, 4 - Babassu stem + coconut fiber + rice husk + soil, 5 - Commercial substrate + soil. Source: Authors.

DQI is a good indicator of the quality of seedlings in nurseries, as it considers the robustness and balance of the phytomass distribution, which are important variables that help to estimate the success of the seedling's performance after installation in the field (Fonseca et al., 2002).

At 200 DAT, Treatment 5 had the highest DQI mean (2.58), being different from the others $(\mathrm{P}<0.05)$. Treatment 1 had the second highest mean (2.06) among the non-commercial treatments, showing that the use of babassu stem in the substrate composition has a positive effect on the quality of assai seedlings.

The data obtained in this study corroborate the research conducted by Araújo Neto et al. (2015), who found that the DQI of seedlings cultivated with substrates formulated with the addition of coconut fiber and palm stem (Attalea phalerata), was higher and differed from those containing other types of materials in their composition.

The average values found in treatments T5 and T1 are close to the value found by Araújo et al. (2019), who observed a DQI of 3.92, at 240 days, in an area with $20 \%$ of shading and with the addition of improved efficiency fertilizers to treatments.

The leaf area (LA) variable shown in Table 4 did not show statistical difference $(\mathrm{P}>0.05)$ between treatments at 100 DAT. At 150 and 200 DAT, treatment 5 (commercial) had the highest average of LA $\left(262.59 \mathrm{~cm}^{2}\right.$ plant $^{-1}$ and $331.04 \mathrm{~cm}^{2}$ plant $^{-1}$, respectively). Treatment 4 had the highest average among the other non-commercial treatments, on both days evaluated (175.12 and $229.49 \mathrm{~cm}^{2}$ plant $^{-1}$, respectively).

The omission of nutrients $\mathrm{N}, \mathrm{P}, \mathrm{K}$ and $\mathrm{Mg}$ in assai seedlings affect the growth and development of the seedlings, in addition to decreasing the number of leaves and restricting the leaf area (Ribeiro Araújo et al., 2016).

The number of leaves in assai seedlings, when in treatments with individual omission of $\mathrm{N}, \mathrm{P}$ and $\mathrm{K}$, is significantly reduced (about 50\%, 33\% and 30\%, respectively), compared to the complete treatments with application of liming, macro and micronutrients (Viégas et al., 2008)

The data found in this study regarding leaf area are close to the values found by Zancheta et al. (2013), who evaluated the growth of Euterpe oleracea seedlings under different shadings and light conditions (70, 50 and $30 \%$ shading). The authors found LA values of $292.68 \mathrm{~cm}^{2}$ at 150 days, and of $290.04 \mathrm{~cm}^{2}$ at 180 days. These values were obtained in the treatment with black shadow at a $50 \%$ brightness, a condition also adopted in this study, in addition to the substrate, which contained in its composition organic residue + soil, and fertilization with simple Superphosphate $\left(10 \mathrm{gL}^{-1}\right)$.

In the present work, the absolute growth rate (AGR) as well as the LA, was higher in the treatment 5 seedlings, at 150 and 200 DAT (0.045 and $0.065 \mathrm{~g}$. plant ${ }^{-1}$.day ${ }^{-1}$, respectively), differing statistically from the others means $(\mathrm{P}<0.05)$. Treatment 4 is the treatment with the highest mean of AGR $\left(0.028 \mathrm{~g}\right.$. plant ${ }^{-1}$.day $\left.{ }^{-1}\right)$ among the non-commercial treatments at 150 DAT and treatment 1 is the highest average at 200 DAT $\left(0.047 \mathrm{~g}\right.$. plant ${ }^{-1}$ day $\left.^{-1}\right)$

When studying the relative growth rate (RGR) in palm trees, Nogueira and Conceição (2000) concluded that in these plants, the RGR depends almost fundamentally on the useful leaf area for photosynthesis and on the assimilation rate, behaving similarly to the rate of absolute growth (AGR), corroborating Lambers and Poorter (1992), who state that growth rate is the product of a morphological component, the leaf area ratio, and a physiological component, the assimilation rate (acquisition rate) of biomass per unit of leaf area.

\section{Conclusion}

The growth and initial development of Euterpe oleracea seedlings are influenced by the type of substrate in which they are cultivated. 
Up to 150 days after transplanting, it was verified that the quality and development of the seedlings, analyzed via Dickson's quality index parameter, were statistically equal, which shows the potential of these materials to compose the formulation of substrates for the production of assai seedlings.

However, it should be noted that the treatment using babassu stem (T1) obtained better SDM, TDM and DQI values, in addition to being a material found in abundance in the Cerrado/Amazon transition regions and also in the Amazon region, which allows for the easy acquisition of the babassu stem, making this treatment the most viable and recommended for the production of assai seedlings.

\section{Acknowledgments}

To the Coordination for the Improvement of Higher Education Personnel (CAPES) and the National Council for Scientific and Technological Development (CNPQ) for the granting of a scholarship and resources made available during the period of the Stricto Sensu Postgraduate Course in Plant Production at the Federal University of Tocantins.

\section{References}

Araújo, J. M. D., Andrade Neto, R. D. C., Oliveira, J. R. D., Lunz, A. M. P., \& Almeida, U. O. D. (2019). Shading and slow-release fertilizer effects on the growth characteristics of assai seedlings (Euterpe oleracea). Floresta e Ambiente, 26(3). Doi: https://doi.org/10.1590/2179-8087.001918. ISSN 2179-8087 (online).

Araújo Neto, S. E., Frednberg, N., Minosso, S., Novelli, D., \& Andrade Neto, R. C. (2015). Condicionadores de substrato para produção orgânica de mudas de cupuaçu. Revista Brasileira de Fruticultura, Jaboticabal, 37(4), 1083-1088. Doi: http://dx.doi.org/10.1590/0100-2945-207/14.

Azevedo, A. A., Stabile, M. C. C., Reis, \& T. N. P. (2015). Commodity production in Brazil: Combining zero deforestation and zero illegality. Elementa: Science of the Anthropocene, v. 3, n. 1, p. 12. Doi: 10.12952/journal.elementa.000076.

Benincasa, M. M. P. (1988). Análise de crescimento de plantas. Jaboticabal: FUNEP. 43p.

Batista, M. J. (2021). Projeto de plantação de açaí no Tocantins é pioneiro no mundo. https://www.to.gov.br/sics/noticias/projeto-de-plantacao-de-acai-notocantins-e-pioneiro-no-mundo/2ytscgwc1cem. Acesso em: 20/02/2021.

Brito almeida, B., Cordeiro, Y. E. M., Beltrão, N. E. S., Tavares, F. B., Sousa, R. L., \& Sousa Nascimento, A. W. (2021). Transformações observadas pelos atores sociais na várzea de Igarapé-Miri (PA) a partir o aumento da produção do açaí (Euterpe oleracea Mart.). Research, Society and Development, 10(10), e173101018548-e173101018548.

BRASIL. Lei 12.651, de 25 de maio 2012. Dispõe sobre a proteção da vegetação nativa. (2012a). <http://www.planalto.gov.br/ccivil_03/_ato20112014/2012/lei/ 112651.htm>.

Caldeira, M. V., Delarmelina, W. M., Peroni, L., Gonçalves, E. D. O., \& Silva, A. G. D. (2013). Lodo de esgoto e vermiculita na produção de mudas de eucalipto. Pesquisa Agropecuária Tropical, 43(2), 155-163. Doi: https://doi.org/10.1590/S1983-40632013000200002.

Companhia Nacional de Abastecimento (CONAB). (2017). Boletim da Sociobiodiversidade. Vol. 5, n.1 (2017- 2021). - Brasília: Conab, 2017- 2021. http://www.conab.gov.br.

Carneiro, A. P.G., Aguiar, A.L. L., Gonzaga, M. L. C.; Soares, D. J, Figueiredo, E. A. T., Sousa, P. H. M., \& Figueiredo, R.W. (2020). Stability of bioactive compounds, antioxidant and microbiological activity of açaí powder (Euterpe oleracea Mart.). Research, Society and Development, 9(7):1-15. e229973810.

Campos, M. A. A., \& Uchida, T. (2002). Influência do sombreamento no crescimento de mudas de três espécies amazônicas. Pesquisa Agropecuária Brasileira, v.37, n.3, p.281- 288.

Correa, B. A., Parreira, M. C., Martins, J. S., Ribeiro, R. C., \& Silva, E. M. (2019). Reaproveitamento de resíduos orgânicos regionais agroindustriais da Amazônia Tocantina como substratos alternativos na produção de mudas de alface. Revista Brasileira de Agropecuária Sustentável,9(1), 97-104. Doi: https://doi.org/10.21206/rbas.v9i1.7970.

Daldegan, J., \& Sambuichi, R. H. R. (2017). Programa de Aquisição de Sementes e Mudas Nativas (PASEM): uma proposta de política pública para fins de regularização ambiental no Brasil. Instituto de Pesquisa Econômica Aplicada - ipea. Brasília: Rio de Janeiro: Ipea, 1990- ISSN 1415-4765. http://repositorio.ipea.gov.br/handle/11058/7431

Dapont, E. C., Silva, J. B. D., \& Alves, C. Z. (2016). Initial development of assai plants under shade gradation. Revista Brasileira de Fruticultura, 38(2). Doi: http://dx.doi.org/10.1590/0100-29452016022.

De Andrade, H. A. F., Costa, N. A., Cordeiro, K. V., De Oliveira Neto, E. D., Albano, F. G., Da Silva-Matos, R. R. S. (2017). Caule decomposto de babaçu (Attlea speciosa Mart.) como substrato para produção de mudas de melancieira. Cultura Agronômica: Revista de Ciências Agronômicas, 26(3), 406-416. Doi: https://doi.org/10.32929/2446-8355.2017v26n3p406-416. 
Delarmelina, W. M., Caldeira, M. V. W., Faria, J. C. T., De Oliveira, E.G., \& Rocha, R. L. F. (2014). Diferentes substratos para a produção de mudas de sesbania virgata. Floresta e Ambiente. Doi:10.4322/floram.2014.027.

Dickson, A., Leaf, A. L., \& Hosner, J. F. (1960). Quality appraisal of white spruce and white pine seedling stock in nurseries. For. Chron., v. 36, p. 1013,1960 .

Fernandes, A. R., Matos, G. S. B., \& Carvalho, J. G. (2013). Deficiências nutricionais de macronutrientes e sódio em mudas de pupunheira. Revista Brasileira de Fruticultura, v. 35, n. 4, p. 1178-1189, 2013. Doi: https://doi.org/10.1590/S0100-29452013000400029.

Foley, J. A., et al. (2011). Solutions for a cultivated planet. Nature, 478(7369), 337-342. Doi:10.1038/nature10452.

Fonseca, É. P., Valéri, S.V., Fonseca, N. A. N., \& Couto, L. (2002). Padrão de qualidade de mudas de Trema micrantha (L.) Blume, produzidas sob diferentes períodos de sombreamento. Rev. Árvore [online]. vol.26, n.4, pp.515-523. ISSN 1806-9088. Doi: https://doi.org/10.1590/S0100-67622002000400015.

Forzza, R. C., et al. (2015). Lista de espécies da flora do Brasil. <http://floradobrasil.jbrj.gov. br/2010/>.

Gonçalves, J. L. M., Santerelli, E.G., Neto, S. P. M., \& Manara, M. P. (2000). Produção de mudas de espécies nativas: substrato, nutrição, sombreamento e fertilização. In: Gonçalves, J. L. M.; Benedetti, V. (Eds.) Nutrição e fertilização florestal. Piracicaba: ESALQ/USP, p.309-350.

Honorio, A. B. M., Sousa, R. M., Marinho, P. H. A., Leal, T. C. A. B., Souza, P.B. (2017). Germinacao de sementes de Euterpe oleraceae (Mart.) em diferentes substratos. Agrarian Academy, 4. Pags: 280-288.

Hunke, P., Mueller, E. N., Schröder, B., \& Zeilhofer, P. (2014). The Brazilian Cerrado: assessment of water and soil degradation in catchments under intensive agricultural use. Ecohydrology, 8 (6), 1154-1180. Doi: 10.1002/eco.1573.

Instituto Brasileiro de Geografia e Estatística - IBGE. Produção da extração vegetal e da silvicultura - PEVS. 2016. https://sidra.ibge.gov.br/pesquisa/pevs/quadros/brasil/2016.

Janssen, R., \& Rutz, D. D. (2011). Sustainability of biofuels in Latin America: risks and opportunities. Energy Policy 39: 5717-5725.

Lambers, H., \& Poorter, H. (1992). Inherent variation in growth rate between higher plants: a search for physiological causes and ecological consequences. Adv. Ecol. Res. 23:187- 261.

Lambin, E.F., \& Meyfroidt, P. (2011). Global land use change, economic globalization, and the looming land scarcity. Proc. Natl. Acad. Sci. U. S. A. 108, 3465-3472. Doi: 10.1073 / pnas. 1100480108.

Ministério do Meio Ambiente- MMA. (2017) Biomas $\quad-\quad$ Cerrado. https://antigo.mma.gov.br/component/search/?searchword=planaveg\&searchphrase=all\&Itemid=180>.

Ministério do Meio Ambiente (MMA). Painel de Legislação- Ecossistemas. https://antigo.mma.gov.br/temas/servi\%C3\%A7os-ambientais/ecossistemas.html.

Plano Nacional de Recuperação da Vegetação Nativa - Planaveg. Versão Preliminar. (2014). <http://www.mma.gov.br/images/arquivo/ 80049/ Planaveg/PLANAVEG_20-11-14_copy.pdf>.

Nogueira, O. L., \& Conceição, H. E. O. D. (2000). Análise de crescimento de açaizeiros em áreas de várzea do estuário amazônico. Pesquisa agropecuária brasileira, 35(11), 2167-2173. Doi: https://doi.org/10.1590/S0100-204X2000001100007 .

Oliveira, M. do S.P. de, Carvalho, J.E.U. de, Nascimento, W.M.O., \& Muller, C.H. (2002). Cultivo do açaizeiro para a produção de frutos. Belém: Embrapa

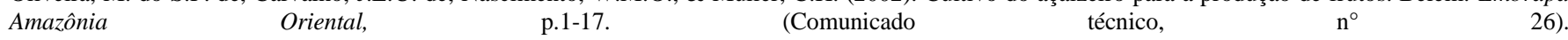
https://www.agencia.cnptia.embrapa.br/Repositorio/Oliveira+et+al.\%252C+2000_000gbtehk8902wx5ok07shnq9dunz6i0.pdf.

Pacheco, R., Rajão, R., Soares-Filho, B., \& Hoff, R. V. D. (2017). Regularização do passivo de reserva legal: percepção dos produtores rurais no pará e mato grosso. Ambiente \& Sociedade, 20(2), 181-200. doi: https://doi.org/10.1590/1809-4422asoc0012r1v2022017.

Peixoto, H., Roxo, M., Krstin, S., Wang, X.J., \& Wink, M. (2016). Anthocyanin-rich extract of Acai (Euterpe precatoria Mart.) Mediates Neuroprotective activities in Caenorhabditis elegans. Journal of Functional Foods, 26, 385-393. Doi: https://doi.org/10.1021/acs.jafc.5b05812

Ribeiro Araújo, F. R., Viégas, I. J.M., Da Cunha, R. L. M., \& Vasconcelos, W. L. F. (2016). Nutrient omission effect on growth and nutritional status of assai palm seedlings. Pesquisa Agropecuária Tropical, 46(4). Doi: http://dx.doi.org/10.1590/1983-40632016v4640770.

Sawyer, D. (2008). Climate change, biofuels and eco-social impacts in the Brazilian Amazon and Cerrado. Philosophical Transactions of the Royal Society, B: Biological Sciences, 363(1498): 1747-1752.

Silva, F. D. M., De Souza, I. V., Zanon, J. A., Nunes, G. M., Da Silva, R. B., \& Ferrari, S. (2015). Produção de mudas de juçara com resíduos agroindustriais e lodo de esgoto compostados. Revista Brasileira de Engenharia de Biossistemas, 9(2), 109-121. Doi: https://doi.org/10.18011/bioeng2015v9n2p109-121.

Serra, F. R. (2020). Análise comercial- Açaí: fruto. Disponível em: $<$ https://www.conab.gov.br/info-agro/analises-do-mercado-agropecuario-eextrativista/analises-do-mercado/historico-mensal-de-acai/item/download/33071_5c082a3c30e899cab253afc67fa8d5db>.

Smiderle, O. J., Souza, A. G., Menegatti, R. D., \& Silva, T. J. (2020). Different substrates for seedling production of Euterpe Oleracea Mart. Advances in Horticultural Science, 34(1), 35-42. Doi: 10.13128/ahsc7651.

Sousa, R. M., Marinho, P. H. A., Honório, A. B. M., Viola, M. R., Alves, M. V. G., \& Souza, P. B. (2018). Diferentes tipos de substrato para a produção de mudas de açaí Euterpe oleracea Mart. Rev. Inst. Flor. v. 30 n. 1 p. 39-45 jun. Doi: http://dx.doi.org/10.24278/2178-5031.201830103.

Sousa, D. M. G., \& Lobato, E. (Ed.). Cerrado: correção do solo e adubação. Planaltina: Embrapa Cerrados, 2002. p.185-226. 
Research, Society and Development, v. 10, n. 17, e76101724345, 2021

(CC BY 4.0) | ISSN 2525-3409 | DOI: http://dx.doi.org/10.33448/rsd-v10i17.24345

Sparovek, G., Berndes, G., Klug, I. L. F., \& Barretto, A. G.O. P. (2010). Brazilian agriculture and environmental legislation: status and future challenges. Environmental Science \& Technology, 44: 6046-53.Doi : https://doi.org/10.1021/es1007824.

Taiz, L., Zeiger, E., Moller, I.M., \& Murphy, A. (2017). [tradução: Alexandra Antunes Mastroberti ... et al. Revisão técnica: Paulo Luiz de Oliveira. - 6. ed. Porto Alegre : Artmed, 2017. Editado como livro. 888 págs. Impresso em 2017. ISBN 978-85-8271-367-9 1.

Viégas, I. J. M., Frazão, D. A. C., Thomaz, M. A. A., Conceição, H. E. O. D., \& Pinheiro, E. (2004). Limitações nutricionais para o cultivo de açaizeiro em latossolo amarelo textura média, Estado do Pará. Revista Brasileira de Fruticultura, 26(2), 382-384. Doi: 10.1590/S0100-29452004000200052.

Viégas, I. J. M., Meirelles, R.O., Frazão, D. A. C., \& Conceição, H. E. O. (2008). Efeito das omissões de macronutrientes e boro na sintomatologia e crescimento em plantas de açaizeiro (Euterpe oleracea Mart.). Revista de Ciências Agrárias, Belém, v. 10, n. 50, p. 129-141, jul./dez.

Zancheta, A. A., Mazzini, R. B., Batista, G. S., Melo, R. F., \& Pivetta, K. F. L. (2013). Growth of Euterpe oleracea seedlings under different color nets and light conditions. In VII International Symposium on New Floricultural Crops 1000 (pp. 293-300). Doi: 10.17660 / ActaHortic.2013.1000.39 